\title{
Muscogee Language
}

National Cancer Institute

\section{Source}

National Cancer Institute. Muscogee Language. NCI Thesaurus. Code C154038.

A Muskogean language spoken by Muscogee (Creek) and Seminole people, primarily in the U.S. states of Oklahoma and Florida. 